\title{
Gradient Analysis of Exotic Species in Pinus radiata Stands of Tenerife (Canary Islands)
}

\author{
S. Fernández-Lugo and J.R. Arévalo*
}

Departamento de Ecología, Facultad de Biología, Universidad de La Laguna, La Laguna 38206, Spain

\begin{abstract}
Identifying the factors that influence the spread of exotic species is essential for evaluating the present and future extent of plant invasions and for the development of eradication programs. We randomly established a network of 250 plots on an exotic Pinus radiata D. Don plantation on Tenerife Island in order to determine if roads and urban centers are favouring the spread of exotic plant species into the forest. We identified four distinct vegetation groups in the $P$. radiata stands: advanced laurel forest (ALF), undeveloped laurel forest (ULF), ruderal (RU), and Canarian pine stand (CPS). The groups farthest from roads and urban nuclei (ALF and CPS) have the best conserved vegetation, characterizing by the main species of the potential vegetation of the area and almost no exotic and ruderal species. On the other hand, the groups nearest to human infrastructures (ULF and RU) are characterized by species from potential vegetation's substitution stages and a higher proportion of exotic and ruderal species. The results indicate distance to roads and urban areas are disturbance factors favouring the presence of exotic and ruderal species into the $P$. radiata plantation. We propose the eradication of some dangerous exotic species, monitoring of the study area in order to detect any intrusion of alien species in the best conserved areas and implementation of management activities to reduce the perturbation of the ULF and RU areas.
\end{abstract}

Keywords: Alien species, DCA, detrended correspondence analysis, distance to roads, distance to urban nuclei, TWINSPAN, two way indicator species analysis.

\section{INTRODUCTION}

The invasibility of ecosystems can be described by a diverse number of factors like climate, geology, historic land use, landscape context, native plant richness, competition with natives, and natural or anthropogenic disturbances [15]. Two of the most important traits shaping the vulnerability of ecosystems to plant invasion are disturbances [3,6], which create favourable conditions for alien plants establishment, and propagule pressure, which provides more opportunities for establishment, persistence, naturalization and invasion of exotic species $[6,7]$.

One of the main factors of disturbance of ecosystems around the world is road infrastructure [8,9], which has proven to have important effects on the native vegetation of oceanic islands [10, 11]. Human corridors contribute to ecosystems invasion by 1) creating new favourable habitats for exotic species establishment [12,13], 2) stressing or removing native species $[12,14], 3)$ facilitating the exotic species' movement by natural or human vectors $[8,10]$ and 4) providing an important source of exotic plant propagules [15]. In addition to roads, the distance to urban nuclei is an important factor influencing the richness of exotics in ecosystems $[16,17]$. In these modified areas the successful invasions are frequent [18], and the horticulture activities that take place are an important pathway for the introduction of alien species $[16,19]$. Due to this, urban nuclei contribute

*Address correspondence to this author at the Facultad de Biología, Departamento de Ecología, Universidad de La Laguna 38206, Spain; Tel: +34922 318 628; Fax: +32922 318 311; E-mail: jarevalo@ull.es to the spread of exotic species into natural areas, acting as an important source of propagule pressure [20].

The Canary archipelago is situated amongst the most heavily roaded European territories [21]. Moreover, in the last four decades the population has doubled, leading to bigger and more urban nuclei [22]. Tenerife Island has a population density of 419 inhabitants per $\mathrm{km}^{2}$, a value above the highest densities of other European Union communities [22]. The island has a total area of 5692 ha occupied for roads, which cover approximately $2.8 \%$ of the island's surface. This situation is of concern in the protected forest areas, where it has been proven that exotic species are expanding along roads [23-25], and that the urban nuclei are contributing to their expansion $[23,25]$.

Most of the actual forests of the Canary Islands are a result afforestation that took place mainly between 1930 and 1950 [26]. Pinus canariensis Chr. Sm. Ex DC. and to a lesser extent Pinus radiata D. Don (approximately 2200 ha in Tenerife Island) were the primary species on these plantations, and they were planted principally in areas with a potential vegetation of Canarian pine forests, but also in areas where laurel forests dominated [26, 27]. As a result, the forested areas of Tenerife Island today occupy a larger surface when compared to their historical distribution [27, 28]. Currently, the potential vegetation of these areas seems to be in a good regeneration state [29]. The increase of protected areas (approximately $48 \%$ of the Tenerife Island surface) as well as the socioeconomic changes of the last few decades (abandonment of traditional land use practices, increase of intensive cultivation and touristic development) also contributed to the recuperation of the forests by 
decreasing or eliminating forestry exploitation, agriculture and grazing activities. As a result of increasing protected areas and ceasing many historical land use activities, we believe road infrastructures and urban nuclei are the most prevalent ways for exotic species to invade the forest ecosystems of Tenerife Island [30].

The main objectives of this study are to determine to what degree the $P$. radiata plantations of Tenerife Island are being affected by exotic plant species and to find out if the presence of these species is related to the distance to paved roads and urban nuclei. Our main hypothesis is that the nearer the roads and urban nuclei are to the studied plots, the higher the number of exotic and ruderal species. Identifying the factors that influence the spread of exotic species is essential for evaluating the present and future extent of plant invasions and for the development of eradication programs $[1,31]$. Consequently, determining the extent to which distance to roads and urban nuclei are leading to the invasion of Canary Island forested areas is fundamental in designing adequate restoration and management programs of these protected areas.

\section{MATERIAL AND METHODS}

\section{Study Site}

The study was carried out in the north-east slope of the Corona Forestal Natural Park and Reserva Especial de las Palomas on Tenerife Island $\left(28^{\circ} 19^{\prime} \mathrm{N}, 16^{\circ} 34^{\prime} \mathrm{W}\right)$, Canary Islands, Spain. The park comprises $46336 \mathrm{ha}$, and is the biggest natural protected area and one of the most extensive forest bodies of the Canary Islands. Most of the forests of the park today are a result of reforestation conducted between 1930 and 1950. These plantations mainly consist of $P$. canariensis (25\% of the park) and to a lesser degree $P$. radiata (approximately $2 \%$ of the park) $[26,27]$. Our study area was planted with $P$. radiata between 1948 and 1952.

The vegetation of the area is comprised of laurel forest (between 600 and $900 \mathrm{~m}$ a.s.1.) dominated by Laurus novocanariensis, Erica scoparia, Erica arborea, Ilex canariensis, Persea indica, Prunus lusitanica, Myrica faya and Viburnum rigidum, and Canarian pine forest (between 1000 and 2000 $\mathrm{m}$ a.s.1.) dominated by $P$. canariensis, and including different understory species like Adenocarpus foliolosus, Bystropogon organifolium, Chamaecytisus proliferus, Erysimum bicolor or Lotus campylocladus.

The annual precipitation of the park reaches $900 \mathrm{~mm}$ but that amount is doubled if fog drip is considered [32]. The average annual temperature is $15^{\circ} \mathrm{C}$. The altitudinal range of the plots is $350 \mathrm{~m}$, implying differences in temperature not over $2{ }^{\circ} \mathrm{C}$ (as well for maximums and minimums), and differences in precipitation around $90 \mathrm{~mm}$ [33]. Soils at the study site have been classified as Entisols, suborder Orthents [34]. Nomenclature and status of species follow Acebes et al. [35].

\section{Vegetation Sampling}

We randomly established 250 quadrat plots of $10 \times 10 \mathrm{~m}$ in size in the $P$. radiata stands. We recorded all the species present in each plot and estimated their percent cover using a 10 point scale (1: traces, $2:<1 \%$ of cover in the plot, $3: 1$ -
$2 \%, 4: 2-5 \%, 5: 5-10 \%, 6: 10-25 \%, 7: 25-50 \%, 8: 50-75 \%$, 9: $>75 \%, 10: 100 \%)$.

We recorded environmental characteristics of the plots, specifically altitude, slope, percentage of bare soil and litter (using same 10 point scale used for species cover), and canopy cover (using a convex spherical densiometer) [36]. We used the software ArcGIS version 9.1 (ESRI) to determine the distance from each plot to the nearest roads and urban nuclei. Sampling was conducted between October 1999 and March 2000.

\section{Statistical Methods}

We used the TWINSPAN method (Two Way Indicator Species Analysis; [37, 38]) to get a classification of ours samples based on their species composition. This divisive and hierarchical technique [37] constructs groups in which constituent species can be considered good indicators of ecological conditions [39]. TWINSPAN uses the quantitative information of the cover for the classification. We highlighted the differences in the same species covering $1 \%$ of the plot or $50 \%$ of the plot creating "TWINSPAN pseudospecies" [37]. We used four categories for the species in relation to their cover at the plot: category 1 means that the species is between 0 and 1 cover classes; category 2 is more than cover class 1 and less than class 2; category 3 more than class 2 and less than 4; and category 4 means more than 4 cover class. In our case, we lessened differences at low cover percentages to increase the calculated dissimilarities. Classes 2 and 3 were given twice the weight of class 1 , while class 4 was three times the weight of class 1 and twice that of classes 2 and 3 .

We used the indirect gradient analysis technique of DCA (Detrended Correspondence Analysis; [40]) to examine how species composition changed through space and whether different classes found with the TWINSPAN method could be extrapolated from the analyses. Analysis was based on the species cover classes and was implemented with the software CANOCO [41].

We used the non parametric Kruskal-Wallis test to look for differences in the distance to roads, distance to urban nuclei and richness values between the vegetation groups defined by the TWINSPAN analysis. We used non parametric tests because the lack of normality and homocedasticity of the data. Normality of the data was tested with the Shapiro-Wilk test, and homoscedasticity of the data was tested with a multiple $F$ test, using a p-value $<0.05$ in both cases. Basic statistical methods followed Zar [42] and were applied with the SPSS statistical package [43].

\section{RESULTS}

We found seven exotic species (not including Pinus radiata) and a total of eighty species in the studied plantations. The alien plant species found were: Ageratina adenophora, Eucaliptus globulus, Linum bienne, Lotus angustissimus, Oxalis pes-caprae, Rumex acetocella and Stellaria media. All the species belong to different families, and with the exception of E. globulus, all of them are herbaceous species.

TWINSPAN analysis based on species cover classes showed four groups. Based on the species present in the 
understory of the $P$. radiata stands in each group, we identified them as: advanced laurel forest (ALF), undeveloped laurel forest (ULF), ruderal (RU), and Canarian pine stand (CPS). The ALF group is dominated by species like Laurus novo-canariensis, Ilex canariensis and Viburnum rigidum, typical from the laurel forest potential vegetation. In the ULF group, the laurel forest species are also present, but in this case there is an important presence of ruderal species like Brachypodium sylvaticum, Galium scabrum and Vicia lutea. The presence of a high number of ruderal species (Sonchus oleraceus, Trifolium arvense,
Tuberaria guttata, Anagallis arvensis, Stachys arvensis, etc) stands out in the RU group. Finally, the species composition of the CPS group is more characteristic of Canarian pine forests, and $P$. canariensis shares the canopy cover with $P$. radiata.

The DCA biplot for the site and species scores (for axes I and II) is shown in Fig. (1). In this graph different symbols have been assigned to the plots of the groups defined by TWINSPAN analysis. In the first axis we can observe a gradient from species characteristic of the laurel forest (Prunus lusitanica, Picconia excelsa, Ilex perado or

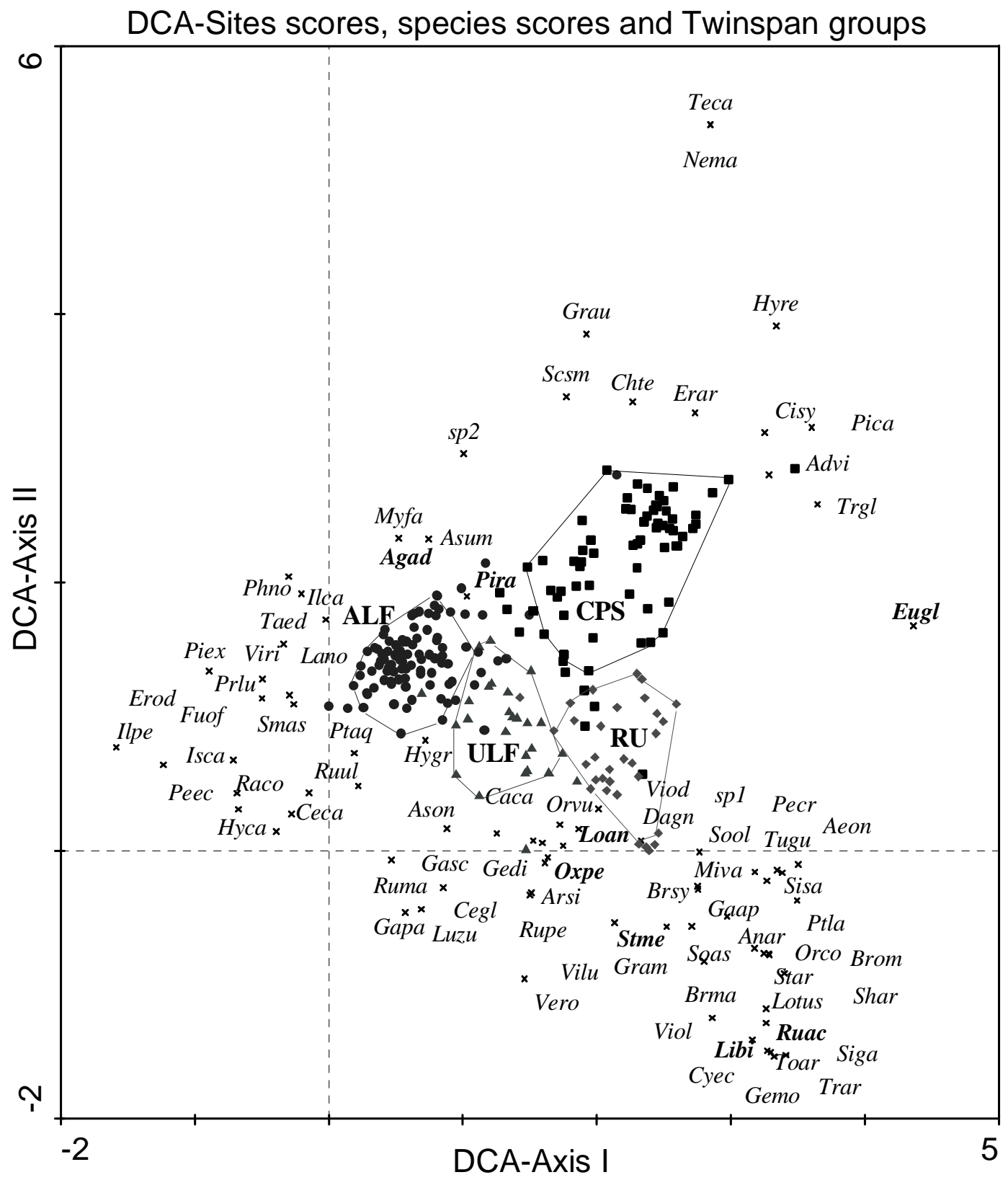

Fig. (1). Species and site scores for the first and second axis of the DCA based on cover of the species (eigenvalues were 0.463 and 0.348 , respectively, and the cumulative percentage variance of species data of both axes was 14.4). The plots belonging to the different TWINSPAN groups are represented with the following symbols: • ALF, $\triangle \mathrm{ULF}, \downarrow \mathrm{RU}, \boldsymbol{\mathrm { CPS }}$ and are enclosed by polygons, which include $95 \%$ of the plots of each group. Species are labelled with the first two letters of the genus followed by the first two letters of the specific epithet (As they appear in Appendix A). The exotic species are in bold. 
Isoplexis canariensis) on the left to ruderal species (Sherardia arvensis, Trifolium arevense, Silene galica or Galium parisiense) on the right. This indicates an ALF-ULFRU gradient. The second axis shows a gradient from the species typical of the Canarian pine forest (Teline canariensis, Neotinea maculata, Hypericum reflexum or Cistus sympithifolius) to the ruderal species. Although this second gradient separates the CPS from the RU group, the species composition of the RU group is more related to the pine forest than to the laurel forest, but the dominance of the ruderal and exotic species in this group displays this gradient.

The exotic species are principally common in the RU group, although they also appear in the ULF group. There are only two exotic species that do not appear in any of these groups: Ageratina adenophona which appears mainly in the ALF group and Eucaliptus globulus which is present only in the CPS group.

The Kruskal-Wallis test showed that the vegetation groups discriminated by the TWINSPAN differ in their distance to the nearest paved roads $\left(\mathrm{X}_{3,245}^{2}=31.181, \mathrm{p}<0.01\right.$; Fig. 2a) and in their distance to the nearest urban nuclei $\left(\mathrm{X}_{3,245}=51.088, \mathrm{p}<0.01 \mathrm{Fig}\right.$. 2b). The groups containing most of the ruderal and exotic species (RU and ULF) are closer to these elements. The RU group is the nearest to both disturbance factors, while the ULF group is also close to paved roads. These two groups have the highest richness values $\left(\mathrm{X}_{3,245}^{2}=152.659, \mathrm{p}<0.01\right.$; Fig. 2c). On the other hand, ALF and CPS, the groups that have less ruderal and exotic species, are a greater distance from these disturbance factors and also have lower species number. A description of the abiotic characteristics of the groups can be found in Table 1.

\section{DISCUSSION}

We found $8.75 \%$ of species in the $P$. radiata stands were exotic. We did not include $P$. radiata in this percentage because it is a shade intolerant species that does not show regeneration in the study area [29]. The vegetation of the $P$. radiata stands could be classified in four groups. Two of them, the advanced laurel forest group (ALF) and the Canarian pine stands group (CPS), have the best conserved vegetation, characterizing by the main species of the potential vegetation of the area and almost no exotic and ruderal species. These groups are the farthest from paved roads and urban nuclei and have smaller richness values. On the other hand, the undeveloped laurel forest group (ULF), which is nearer to roads than the ALF and CPS groups, has the characteristic species of the laurel forest but they are accompanied by a remarkable number of ruderal species and some exotic species in the understory. This group also has high richness values, which can be a feature of disturbed ecosystems [44, 45]. Finally, the ruderal group (RU), which is more related to Canarian pine forests than to laurel forests, has the highest proportion of exotic and ruderal species as well as the highest species richness, typical traits of plots close to trails or those affected by other disturbances [26]. These results support our hypothesis that roads and urban nuclei are affecting the species composition of the nearest ecosystems, favoring the invasion by ruderal and exotic species [23-25]. Our results suggest that when both factors are present, as in the case of the RU group, the effects on the vegetal communities are more evident than if only one is present, as in the case of the ULF group.

(a)

\section{Distance to roads}

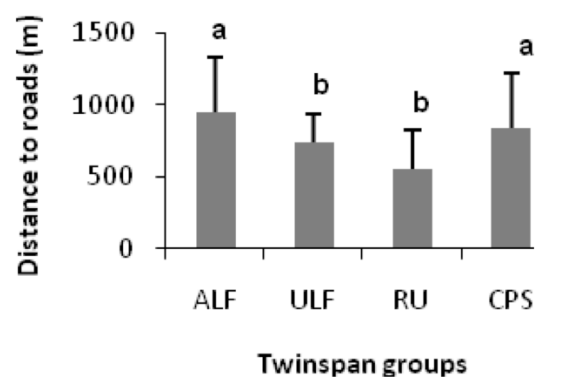

(b)

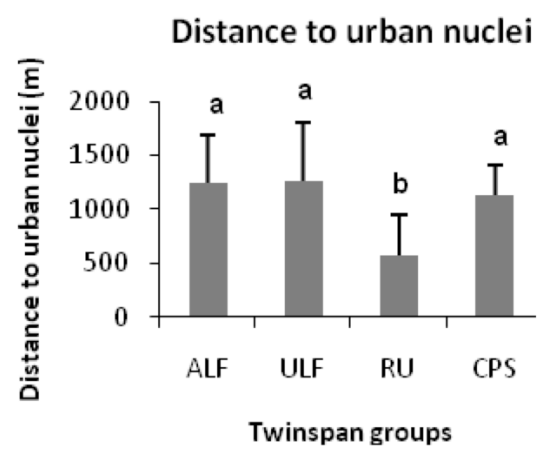

(c)

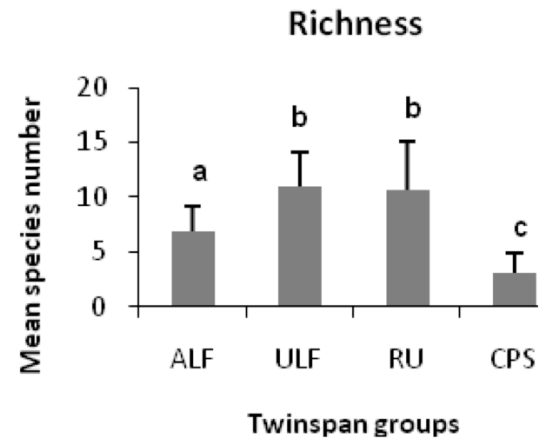

Fig. (2). Mean values and standard deviations for (a) distance to roads (meters); (b) distance to urban nuclei (meters); (c) richness (species number). Identical letters above the bars indicate nonsignificant differences.

Road infrastructure is one of the main ways exotic plant species invade natural areas, especially for generalist annual species $[10,46,47]$. The edges of these corridors provide adequate habitats for the exotic species' establishment, facilitating their dispersion [48]. Several studies show that a considerable number of ruderal and exotic species are spreading along road edges in the Canary Islands [23-25] even finding nearly three times as many species (including native and non-native species) on the road edge than $90 \mathrm{~m}$ inside of the laurel and pine forests [49]. Although in these studies the alien species' presence was limited to a few meters inside of the forests we found a significant number of alien species inside of the $P$. radiata stands. This divergence might be a result of the differences in the forested areas. In our study, the sites are not natural laurel and Canarian pine 
forests but an exotic pine plantations. In $P$. radiata stands, forest uses have been carried out to decrease the populations of this pine species, and the disturbances generated by these activities might be allowing alien and ruderal species to invade the interior of the forests [50].

Table 1. Mean Values for Altitude (Meters); Slope (Sexagesimal Degrees); Canopy Cover (Mean of the Percentages); and Litter, Rock and Soil Cover (Mean of Cover Classes for the Plots) of the Different Groups Discriminated by TWINSPAN Analysis

\begin{tabular}{|c|c|c|c|c|}
\hline & ALF & ULF & RU & CPS \\
\hline \hline Altitude & 974.75 & 1029.31 & 1122.97 & 1222.03 \\
\hline Slope & 16.99 & 8.58 & 8.56 & 11.73 \\
\hline Canopy cover & 87.52 & 75.72 & 82.36 & 81.88 \\
\hline Litter & 8.96 & 8.42 & 8.22 & 8.51 \\
\hline Rock & 1.92 & 2.23 & 3.81 & 3.99 \\
\hline Soil & 1.21 & 1.81 & 2.13 & 1.82 \\
\hline
\end{tabular}

When close proximity to roads is combined with a short distance to urban nuclei, the presence of alien species in the $P$. radiata stands is even greater. Distance to population nuclei has proven to be an important factor determining the richness of ruderal and exotic species in forests $[16,17]$. In the Canary Islands the number of ruderal and exotic species presents in roads decreases as the distance to the urban nuclei increases [23, 25]. These results support the hypothesis that the combination of both factors could make the invasion process stronger.

Three of the exotic species found in this study are considered highly invasive in the Canary Islands: Ageratina adenopora [51], Oxalis pes-caprae [52] and Eucalyptus globulus [28]. The first of these has been frequently found on the road edges of the Canarian ecosystems [23, 25, 49], but it also appears in natural ecosystems [53] in competition with the native and endemic flora. We found this species mainly in the laurel forest, which is considered the most representative Canarian ecosystem [54]. Avoiding the expansion of this species into the laurel forests must be of primary importance for the management of this protected area. We suggest that eradication plans should be implemented for this species as soon as possible. O. pescaprae mainly invades ruderal, agricultural, grasslands and old-field habitats [55]. In the Canary Islands this species has been found mainly on road edges [23-25] and in pasture communities [56]. It was not frequently found in the $P$. radiata stands, and it appeared mainly in the disturbed plots, so in this case eradication measurements are not necessary, although a monitoring of the species must be carried out. Finally, E. globulus is an exotic species that was introduced to the Canary Island for forest purposes. The presence of this species in the CPS group plots is restricted to areas where it was originally planted. This species does not show regeneration but produces changes in the chemical properties and nutrient impoverishment of the soils [57]. Because of this and because its forest use is not current, we suggest the elimination of this tree species of the studied areas.

The rest of the exotic species found in this study are not highly invasive and appear mainly in more disturbed areas.
Therefore we recommend continued monitoring of the study site in order to detect any intrusion of the alien species in the best conserved places. Moreover in the RU and ULF group areas, management activities should be implemented to reduce the perturbation of the ecosystem and to promote successful regeneration of the potential vegetation [29].

\section{ACKNOWLEDGEMENTS}

The authors are thankful for financial support from "Cabildo Insular de Tenerife", "Sección de Montes", and the Spanish Ministry of Science and Innovation for the FPU scholarship for Silvia Fernández Lugo. We are grateful to Beatriz Mora for her help with the measurement of the plots and to Enrique Coello for his help with data analysis.

\section{APPENDIX A}

Species found in this study and labels given to them in the DCA analysis. Exotic species are given in bold.

\begin{tabular}{|c|c|c|c|}
\hline Species & Labels & Species & Labels \\
\hline Adenocarpus viscosus & Advi & Myrica faya & Myfa \\
\hline Aeonium sp. & Aeon & Neotinea maculata & Nema \\
\hline Ageratina adenophora & Agad & Origanum vulgare & Orvu \\
\hline Anagallis arvensis & Anar & Ornithopus compressus & Orco \\
\hline Arisarum simorrhinum & Arsi & Oxalis pes-caprae & Oxpe \\
\hline Asparragus umbellatus & Asum & Pericallis cruenta & Pecr \\
\hline Asplenium onopteris & Ason & Pericallis echinata & Peec \\
\hline Brachypodium sylvaticum & Brsy & Phyllis nobla & Phno \\
\hline Briza maxima & Brma & Picconia excelsa & Piex \\
\hline Bromus sp. & Brom & Pinus canariensis & Pica \\
\hline Carex canariensis & Caca & Pinus radiata & Pira \\
\hline Cedronella canariensis & Ceca & Prunus lusitanica & Prlu \\
\hline Cerastium glomeratum & Cegl & Pteridium aquilinum & Ptaq \\
\hline Cheirolophus teydis & Chte & Pterocephalus lasiospermus & Ptla \\
\hline Cistus symphytifolius & Cisy & Ranunculus cortusifolius & Raco \\
\hline Cynosorus echinatus & Cyec & Rubia peregrina & Rupe \\
\hline Daphne gnidium & Dagn & Rubus ulmifolius & Ruul \\
\hline Erica arborea & Erar & Rumex acetocella & Ruac \\
\hline Erodium sp. & Erod & Rumex maderensis & Ruma \\
\hline Eucaliptus globulus & Eugl & Scrophularia smitti & Scsm \\
\hline Fumaria officinalis & Fuof & Sherardia arvensis & Shar \\
\hline Galium aparine & Gaap & Silene gallica & Siga \\
\hline Galium parisiense & Gapa & Smilax aspera & Smas \\
\hline Galium scabrum & Gasc & Sonchus asper & Soas \\
\hline Geranium dissectum & Gedi & Sonchus oleraceus & Sool \\
\hline Geranium molle & Gemo & Unknown sp. (1) & $\mathrm{sp} 1$ \\
\hline Gramineae & Gram & Unknown sp. (2) & $\mathrm{sp} 2$ \\
\hline Greenovia aurea & Grau & Stachis arvensis & Star \\
\hline Hypericum canariense & Hyca & Stellaria media & Stme \\
\hline Hypericum grandifolium & Hygr & Tamus edulis & Taed \\
\hline Hypericum reflexum & Hyre & Teline canariensis & Teca \\
\hline Ilex canariensis & Ilca & Torilis arvensis & Toar \\
\hline Ilex perado & Ilpe & Trifolium arvense & Trar \\
\hline Isoplexis canariensis & Isca & Trifolium glomeratum & Trgl \\
\hline Laurus novo-canariensis & Lano & Tuberaria guttata & Tugu \\
\hline Linum bienne & Libi & Veronica sp. & Vero \\
\hline Lotus & Lotus & Viburnum rigidus & Viri \\
\hline Lotus angustissimus & Loan & Vicia lutea & Vilu \\
\hline Luzula sp. & Luzu & Viola odorata & Viod \\
\hline Micromeria varia & Miva & Viola sp. & Viol \\
\hline
\end{tabular}




\section{REFERENCES}

[1] Alpert P, Bone E, Holzapfel C. Invasiveness, invasibility and the role of environmental stress in the spread of non-native plants. Perspect Plant Ecol Evol Syst 2000; 3: 52-66.

[2] Crawley M, Harvey P, Purvis A. In: Silvertown J, Franco M, Harper J, Eds. Plant Life Histories: Ecology, Phylogeny and Evolution. Cambridge: Cambridge University Press 1997; pp. 3653.

[3] Pysěk P, Jarošík V, Kučera T. Patterns of invasion in temperate nature reserves. Biol Conserv 2002; 104: 13-24.

[4] Rejmánek M, Richardson DM, Pysěk P. In: van der Maarel E, Ed. Vegetation Ecology. Oxford: Blackwell Science 2005; pp. 332-55.

[5] Richardson DM, Pysěk P, Rejmánek M, Barbour MG, Panetta FD, West CJ. Naturalization and invasion of alien plants: concepts and definitions. Divers Distrib 2000; 6: 93-107.

[6] Lonsdale WM. Global patterns of plant invasions and the concept of invasibility. Ecology 1999; 80: 1522-36.

[7] Rouget M, Richardson DM. Inferring process from pattern in plant invasions: a semimechanistic model incorporating propagule pressure and environmental factors. Am Nat 2003; 162: 713-24.

[8] Forman RTT, Alexander LE. Roads and their major ecological effects. Ann Rev Ecol Syst 1998; 29: 207-31.

[9] Forman RTT, Bissonette J, Clevenger A, et al. Road Ecology: Science and Solutions. Washington: Island Press 2002.

[10] Parendes LA, Jones JA. Role of light availability and dispersal in exotic plant invasion along roads and streams in the H.J. Andrews experimental forest, Oregon. Conserv Biol 2000; 14: 64-75.

[11] Daehler CC. Upper-montane plant invasions in the Hawaiian Islands: Patterns and opportunities. Perspect Plant Ecol Evol Syst 2005; 7: 203-16

[12] Brothers TS, Spingarn A. Forest fragmentation and alien plant invasion of central Indiana old-growth forests. Conserv Biol 1992; 6: 91-100.

[13] Gehlhausen SM, Schwartz MW, Augspurger CK. Vegetation and microclimatic edge effects in two mixedmesophytic forest fragments. Plant Ecol 2000; 147: 21-35.

[14] Yates ED, Levia DF, Williams CL. Recruitment of three non-native invasive plants into a fragmented forest in southern Illinois. For Ecol Manage 2004; 190: 119-30.

[15] Milberg P, Lamont BB. Fire enhances weed invasion of roadside vegetation in southwestern Australia. Biol Conserv 1995; 73: 45-9.

[16] Alston K, Richardson DM. The roles of habitat features, disturbance, and distance from putative source populations in structuring alien plant invasions at the urban/wildland interface on the Cape Peninsula, South Africa. Biol Conserv 2006; 132: 183-98.

[17] Timmins SM, Williams PA. Weed numbers in New Zealand's forest and scrub reserves. NZJ Ecol 1991; 15: 153-62.

[18] Niemelä J. Ecology and urban planning. Biodivers Conserv 1999; 8: 119-31.

[19] Richardson DM, Cambray JA, Chapman RA, et al. Eds. Invasive Species: Vectors and Management Strategies. Washington: Island Press 2003; pp. 292-349.

[20] Aragón R, Morales JM. Species composition and invasion in NW Argentinian secondary forests: Effects of land use history, environment and landscape. J Veg Sci 2003; 14: 195-204.

[21] Fernández-Palacios JM, Martín Esquivel JL. Naturaleza de las Islas Canarias Ecología y Conservación. Santa Cruz de Tenerife: Turquesa Ediciones 2001.

[22] Fernández-Palacios JM, Arévalo JR, Delgado JD, Otto R. Canarias: ecología, medio ambiente y desarrollo. Centro de la Cultura Popular Canaria, España 2004.

[23] Arévalo JR, Delgado JD, Otto R, Naranjo A, Salas M, FernándezPalacios JM. Distribution of alien vs Native plant species in roadside communities along an altitudinal gradient in Tenerife and Gran Canaria (Canary Islands). Perspect Plant Ecol Evol Syst 2005; 7: $185-202$.

[24] Arévalo JR, Delgado JD, Fernández-Palacios JM. Changes in plant species composition and litter production in response to roads and trails in the laurel forest of Tenerife (Canary Islands). Plant Biosyst 2008; 42: 614-22.

[25] Arteaga MA, Delgado JD, Otto R, Fernández-Palacios JM, Arévalo JR. How do alien plants distribute along roads on oceanic islands? A case study in Tenerife, Canary Islands. Biol Invasions 2009; 11: 1071-86.
[26] Ceballos L, Ortuño F. Vegetación y Flora Forestal de las Canarias Occidentales. 2nd ed. Santa Cruz de Tenerife: Cabildo Insular de Tenerife 1974.

[27] Del Arco MJ, Pérez de Paz PL, Salas M, Wildpret W. Atlas Cartográfico de los Pinares Canarios. Viceconsejería de Medio Ambiente, Santa Cruz de Tenerife; 1992.

[28] Delgado JD, Arévalo JR, Fernández-Palacios JM. In: FernándezPalacios J, Martín JL, Eds. Naturalezade las Islas Canarias. Ecología y Conservación. Naturaleza de las Islas Canarias Ecología y Conservación. Turquesa Ediciones, Santa Cruz de Tenerife, 2001; 173-9.

[29] Arévalo JR, Fernández-Palacios JM. Gradient analysis of exotic Pinus radiata plantations and potential restoration of natural vegetation in Tenerife, Canary Islands (Spain). Acta Oecol 2005; 27: $1-8$

[30] Delgado JD, Arroyo NL, Arévalo JR and Fernández-Palacios JM. Edge effects of roads on temperature, light, canopy cover, and canopy height in laurel and pine forests (Tenerife, Canary Islands). Landsc Urban Plan 2007; 81: 328-40

[31] Rejmánek M, Pitcairn MJ. In: Veitch CR, Clout MN, Eds. Turning the Tide: the Eradication of Invasive Species. IUCN SSC Invasive Species Specialist Group, Gland and Cambridge, 2002; pp. 249-53.

[32] Kämmer F. Klima und vegetation auf Tenerife, besonders in Hinblick auf den Nebelniederschlag. Scr Geobot 1974; 7: 1-78.

[33] Marzol V. In: Fernández-Palacios J, Martín JL, Eds. Naturalezade las Islas Canarias. Ecología y Conservación. Naturaleza de las Islas Canarias Ecología y Conservación. Santa Cruz de Tenerife: Turquesa Ediciones 2001; pp. 87-93.

[34] Fernández-Caldas E, Tejedor M, Quantin P. Los SuelosVolcánicos de Canarias. Servicio de Publicaciones, Universidad de La Laguna, LaLaguna, 1985.

[35] Acebes JR, del Arco M, García A, et al. In: Izquierdo I, Martín JL Zurita N, Arechavaleta M, Eds. Lista de especies silvestres de Canarias (hongos, plantas y animales terrestres). Consejería de Medio Ambiente y Ordenación Territorial, Gobierno de Canarias, 2004; pp. 96-143.

[36] Lemmon PE. A new instrument for measuring forest overstory density. J For 1957; 55: 667-8.

[37] Hill MO. TWINSPAN. A FORTRAN Program for Arranging Multivariate Data in an Ordered Two-Way Table by Classification of Individuals and Attributes. Cornell University, Ithaca 1979.

[38] Hill MO, Bunce RGH, Shaw MV. Indicator species analysis, a divisive polythetic method of classification, and its application to survey of native pinewoods in Scotland. J Ecol 1975; 63: 597-613.

[39] Lepš J, Šmilauer P. Multivariate Analysis of Ecological Data using CANOCO. Cambridge: Cambridge University Press 2003.

[40] Hill MO, Gauch HJ. Detrended correspondence analysis, an improved ordination technique. Vegetatio 1980; 42: 47-58.

[41] Ter Braak CJF, Šmilauer P. CANOCO Reference Manual and User's Guide to Canoco for Windows, Software for Canonical Community Ordination. Microcomputer Power, Ithaca; 1998.

[42] Zar JH. Biostatistical Analysis. 2nd ed. Englewood Cliffs, NJ: Prentice-Hall 1984.

[43] SPSS. SPSS/PC+ V.6.0. Base manual. SPSS Inc., Chicago, IL 1986.

[44] Grime JP. Plant strategies and vegetation processes. New York: J. Wiley 1979.

[45] Huston M. A general hypothesis of diversity. Am Nat 1979; 113: 81-101.

[46] Dietz H, Edwards PJ. Recognition that causal processes change during plant invasion helps explain conflicts in evidence. Ecology 2006; 87: 1359-67.

[47] Pauchard A, Alaback PB. Influence of elevation, land use, and landscape context on patterns of alien plant invasions along roadsides in protected areas of south-central Chile. Conserv Biol 2004; 18: 238-48.

[48] Benninger-Truax M, Vankat, JL, Schaefer RL. Trail corridors as habitat and conduits for movement of plant species in Rocky Mountain National Park, Colorado. Landsc Ecol 1992; 6, 269-78.

[49] Delgado JD, Arévalo JR, Fernández-Palacios JM. In FernándezPalacios JM, Morici C, Eds. Island Ecology. Asociación Española de Ecología Terrestre (Aeet)-Cabildo Insular de La Palma, 2004; pp. 181-225.

[50] Dodson EK, Fiedler CE. Impacts of restoration treatments on alien plant invasion in Pinus ponderosa forests, Montana, USA. J Appl Ecol 2006; 46: 887-97. 
[51] Bañares A. Recuperación de la flora amenazada de los parques nacionales canarios. Metodología para su planificación y ejecución. Ecología 8: 227-44

[52] Kunkel G. In: Kunkel G. Ed. Biogeography and ecology in the Canary Islands, Junk. La Haya 1976; pp. 249-66.

[53] Bermúdez AM, Fernández-Palacios JM, González-Mancebo JM, Arévalo JR, Otto R, Delgado JD. Floristic and structural recovery of a laurel forest community after clear-cutting: A 60 years chronosequence on La Palma (Canary Islands). Ann For Sci 2007; 64: 109-19.

[54] Arévalo JR. Organización espacial y temporal de la laurisilva de Anaga-Tenerife. Islas Canarias. PhD Dissertation, Universidad de La Laguna. La Laguna 1998.
Gimeno I, Vilá M, Hulme PH. Are islands more susceptible to plant invasion than continents? A test using Oxalis pes-caprae in the western Mediterranean. Ann Bot 2006; 97: 1055-62.

[56] Fernández-Lugo S, de Nascimento L, Mellado M, Bermejo LA, Arévalo JR. Vegetation change and chemical soil composition after four years of goat grazing exclusion in a Canary Islands pasture. Agric Ecosyst Environ 2009; 132: 276-82.

[57] González M, González A. In: Fernández-Palacios J, Martín JL, Eds. Naturalezade las Islas Canarias. Ecología y Conservación. Naturaleza de las Islas Canarias Ecología y Conservación. Santa Cruz de Tenerife: Turquesa Ediciones 2001; pp. 199-205.

(C) Fernández-Lugo and Arévalo; Licensee Bentham Open.

This is an open access article licensed under the terms of the Creative Commons Attribution Non-Commercial License (http://creativecommons.org/licenses/bync/3.0/) which permits unrestricted, non-commercial use, distribution and reproduction in any medium, provided the work is properly cited. 